\title{
APPLICABILITY OF CARBON FIBRES IN REFRACTORY CEMENT COMPOSITES
}

\author{
Ondřej HolčapeK*, Pavel Reiterman, Petr Konvalinka
}

\author{
Czech Technical University in Prague, Faculty of Civil Engineering, Experimental Centre, Thákurova 7, 16629 \\ Prague 6, Czech Republic \\ * corresponding author: ondrej.holcapek@fsv.cvut.cz
}

\begin{abstract}
The main objective of this article is to present the influence of high temperatures on mechanical properties of advanced refractory cement composite reinforced with carbon fibres. The presented material is suitable for industrial applications and can withstand elevated temperatures up to $1000^{\circ} \mathrm{C}$. The action of high temperatures was investigated on two temperature levels $600{ }^{\circ} \mathrm{C}$ and $1000^{\circ} \mathrm{C}$ and was compared to reference specimens dried at $105^{\circ} \mathrm{C}$. The carbon fibres with flexural strength of $4100 \mathrm{MPa}$ were applied in dosage $0.50 \%, 0.75 \%$ and $1.00 \%$ of the total volume. The second investigated modification was mutual ratio between aluminous cement and fine ceramic powder. The influence of high temperatures was investigated by measuring the bulk density, compressive and flexural strength, dynamic modulus of elasticity and fracture energy; all measured on prismatic specimens $40 \times 40 \times 160 \mathrm{~mm}$. The workability of fresh mixture was limited by the maximum dosage of carbon fibres in $1 \%$ of the total volume. Based on the workability and evaluation of residual mechanical properties after temperature loading, the best was found to be the combination of carbon fibres in dosage of $0.75 \%$ by volume.
\end{abstract}

KEYWORDS: aluminous cement; carbon fibres; high temperatures; fracture energy.

\section{INTRODUCTION}

The area of refractory composites provides a wide range of solutions based on various binder or filler systems, temperature of application, type of bond, etc. We can recognize two main categories of refractory materials - cement based composites and ceramics; this article will focus on the cement based composites. Binders can be split up in four major groups based on the bonding system: hydraulic, chemical (organic or inorganic) and ceramic bonding [1]. The hydraulic bond is created by a hydration of aluminous cement, where the final refractory properties are influenced by total amount of $\mathrm{Al}_{2} \mathrm{O}_{3}$, and it is described in the following article. The phosphate materials (for example magnesia-phosphate) represent the example of the chemical bond, especially due to their high melting point [2]. Composites based on these types of bonds are also know as no-cement castables (NCC) 3. The ceramic bond usually starts at temperatures up to $800^{\circ} \mathrm{C}$ and the first heating is necessary for a successful formation of this type of bond, it is usually called sintering. The ceramic bond is usually formed between the grains and the matrix as well as in the matrix itself [4.

The design of fibre-reinforced cement composite materials resistant to high temperatures involves three major aspects: resistance of the matrix, resistance of the fibres and compatibility of the fibres with the matrix in high-temperature conditions (cohesion before and after exposure to high temperatures). Every material used in the refractory composite has an appropriate temperature range of application.
Application of fibres. Two main principles for the fibre application in cement composites that are exposed to elevated temperatures can be defined - to achieve better mechanical characteristics (together with resistance) and to provide a free space for evaporating water. Using the polyethylene fibres in structural concrete leads to an increase of its fire-resistance where the fibres burn out and the water expands into the free space, which leads to a decrease of pressure of the evaporating water and the spalling from the surface is limited [5]. However, the polypropylene fibres may lead to a small reduction in the compressive strength [6]. In the basic principle, this type of fibres does not improve mechanical properties after the action of elevated temperatures. Fibres have a positive influence on the long-term behaviour of the composite exposed to an elevated temperature, gradual changes of temperature or thermal shock. Very positive effect of fibres was achieved in eliminating the cracks and micro-cracks in the composite structure. A dosage of $1.0 \%$ of volume of basalt fibres eliminates the cracks on surface even after an exposure to a cyclic load at $1000^{\circ} \mathrm{C}[7$. Also, the drying process could cause cracks, therefore, the fibres limit the crack propagation 8 . The steel fibres are not suitable for the purpose of refractory composite, due to the decrease of steel's strength at approximately $600^{\circ} \mathrm{C}$ (especially during a long-term action of elevated temperature) [9]. For decades, the asbestos was the most successful solution for the production of fire-safety or fire-resistant materials, including cement composites (this material is also well known for its 


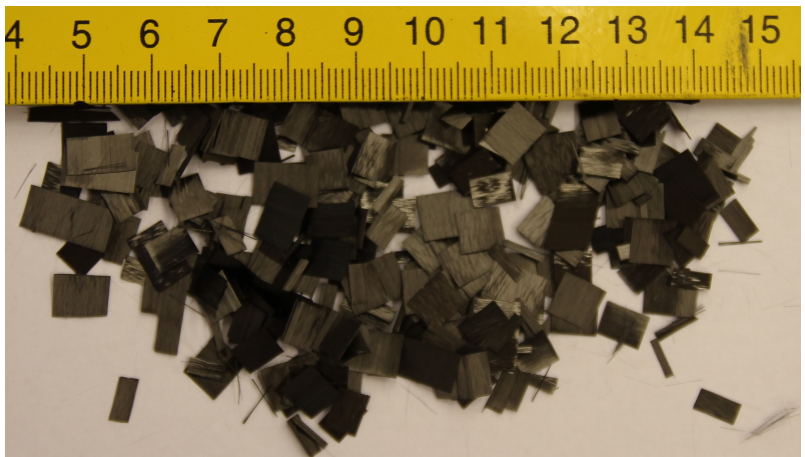

Figure 1. Carbon fibres (Tenax® - A HTC124) $12 \mathrm{~mm}$.

long-term durability). Due to several research works focused on health risks of asbestos [10, the use of this material has been strictly prohibited by standards and government regulations. The carcinogens material (asbestos) has been replaced by modern materials like basalt, carbon, glass, ceramic, etc. [11].

The amount of fibres (optimal dosage and also the maximal dosage) in the cement composites mixture depends on the required properties, type of application, used aggregate, micro-filler, type and the purpose of composite, cement, liquid admixture, etc. The essential part is also the material of used fibres, the geometry or possible treatment of its surface. For the purpose of the ultra-high performance fibre reinforced concrete (UHPFRC), the high strength steel fibres are commonly used, where the optimal dosage oscillates from $1.5 \%$ to $2.0 \%$ of volume [12, 13]. The optimal dosage of fibres in the field of refractory composite has also been investigated, where the amount from $1.0 \%$ to $2.0 \%$ of basalt fibres can be classified as suitable for an elevated environment [14]. The optimal dosage of ceramic fibres can be found in a level about $4.0 \%$ [15]. A composite with this amount of fibres achieved highest mechanical properties, while the self-compacting characteristics are maintained usually with a high dosage of plasticizers.

\section{Development of the Composite}

A natural crushed basalt aggregate of two fractions $(0 / 4$ and $2 / 5 \mathrm{~mm})$ limits the temperature range of application. The sieve test of basalt aggregate and fine ground ceramic powder had been performed before the design started. The following paragraphs deal with other main components; for completeness, the potable water and superplasticizer Sika SVC1035 were used. Thanks to the superplasticizer, the fresh mixture achieved parameters of self-compacting concrete. Jogl et al. in [16] showed that the dosage of the superplasticizer does not significantly affect the final strength properties of a refractory composite.

Calcium aluminous cement (CAC). The used CAC Secar71 (commercially available) achieved 70.8\% $\mathrm{Al}_{2} \mathrm{O}_{3}$. A detailed chemical composition is shown in Table 1. The cement, thanks to the high amount of
$\mathrm{Al}_{2} \mathrm{O}_{3}$, is suitable for an application over $1600^{\circ} \mathrm{C}$. This high utility material is produced by burning of the artificial bauxite in an electric furnace. The boundary conditions rapidly influence the hydration process of the aluminous cement, final properties and the stability of hydration products. It is well known that the reaction of calciumaluminate $(\mathrm{CA})$ with water forms various hydration products according to the curing temperature. The following equations describe the dependence of the hydration on the temperature [17, 18, where the standard convention is used $(\mathrm{CaO}=\mathrm{C}$, $\left.\mathrm{Al}_{2} \mathrm{O}_{3}=\mathrm{A}\right)$ :

$$
\begin{aligned}
(\mathrm{CA})_{m}+\mathrm{H}_{n} \longrightarrow & \left(15-22^{\circ} \mathrm{C}\right) \mathrm{CAH}_{10} \text { gel }, \\
(\mathrm{CA})_{m}+\mathrm{H}_{n} \longrightarrow & \left(23^{\circ} \mathrm{C}\right) \mathrm{C}_{2} \mathrm{AH}_{8}+\mathrm{AH}_{3} \text { gel }, \\
(\mathrm{CA})_{m}+\mathrm{H}_{n} \longrightarrow\left(30-35^{\circ} \mathrm{C}\right) \mathrm{C}_{3} \mathrm{AH}_{6}+\mathrm{AH}_{3} \text { gel } & \\
& \text { or } \mathrm{C}_{3} \mathrm{AH}_{6}+\mathrm{AH}_{3} \text { crystalline. }
\end{aligned}
$$

The threshold temperature for the composite based on ordinary Portland cement is $400{ }^{\circ} \mathrm{C}$, when the portlandite $-\mathrm{Ca}(\mathrm{OH})_{2}$ decomposes to water and lime. The influence of elevated temperatures on the composite on the basis of CAC starts by a dehydration of $\mathrm{CAH}_{10}$ and $\mathrm{C}_{2} \mathrm{AH}_{8}$ [19. The $\mathrm{C}_{12} \mathrm{~A}_{7}$ is the first observable dehydration product. $\mathrm{CA}_{2}$ is detected at a temperature of about $600{ }^{\circ} \mathrm{C}$ and it is a product of the thermal decomposition of $\mathrm{AH}_{3}$. The lowest strength of the aluminous cement is achieved between $800^{\circ} \mathrm{C}$ and $900^{\circ} \mathrm{C}$, when the $\mathrm{CAH}$ is completely decomposed and the formation of ceramic bond still has not occurred [19].

Carbon fibres. The role of carbon fibres lies in improving of the service properties, mainly increase in heat, corrosion and crack resistance of refractory materials [20. Kashcheev et al. implied [11] that the main effect of carbon fibres lies in the change of the failure mechanism and increase in the fracture toughness; the optimal concentration of fibres in refractory cement composites was $0.05 \%$ of weight. Carbon fibres (Tenax® - A HTC124), $12 \mathrm{~mm}$ in length, were used to reinforce the investigated refractory cement composite and are shown on Figure 11 The properties of these fibres are: tensile strength $4100 \mathrm{MPa}$, modulus of elasticity $225 \mathrm{GPa}$, diameter $7 \mu \mathrm{m}$ and bulk density $3000 \mathrm{~kg} / \mathrm{m}^{3}$.

Fine ceramic powder. The binder system of cement refractories is usually supplemented and modified by various types of fine fillers. For the purpose of described refractory composite, a fine ground ceramic powder was used. It is a waste product from the grinding process of a brick blocks production. Due to the content of amorphous phases, approximately $40 \%$, exhibits pozzolanic properties. Various studies investigated a possible application of fine fractions of recycled concrete in cement composites [21]. Ceramic powder has its use as a partial replacement of cement in modern concrete mixes [22], for limecement plaster [23] due to the pozzolanic properties, 


\begin{tabular}{lcccccccccc}
\hline Component & $\mathrm{Al}_{2} \mathrm{O}_{3}$ & $\mathrm{CaO}$ & $\mathrm{SiO}_{2}$ & $\mathrm{Fe}_{2} \mathrm{O}_{3}$ & $\mathrm{Na}_{2} \mathrm{O}$ & $\mathrm{MgO}$ & $\mathrm{K}_{2} \mathrm{O}$ & $\mathrm{TiO}_{2}$ & Unidentified & Specific surface \\
\hline Secar®71 & 70.8 & 27.5 & 0.58 & 0.42 & 0.17 & 0.21 & - & 0.32 & - & $381 \mathrm{~m}^{2} / \mathrm{kg}$ \\
Ceramic powder & 20.26 & 10.92 & 50.73 & 6.36 & 0.9 & 4.75 & 2.43 & - & 3.65 & $336 \mathrm{~m}^{2} / \mathrm{kg}$ \\
\hline
\end{tabular}

TABLE 1. Chemical composition of used fine components [wt. \%].

\begin{tabular}{|c|c|c|c|c|c|c|c|c|}
\hline \multicolumn{3}{|c|}{ Carbon fibres Tenax® } & \multicolumn{2}{|c|}{ Basalt aggregates } & \multicolumn{2}{|c|}{ Fine components } & \multicolumn{2}{|c|}{ Liquid } \\
\hline $\begin{array}{c}0.50 \% \\
8.7 \mathrm{~kg} / \mathrm{m}^{3}\end{array}$ & $\begin{array}{c}0.75 \% \\
13.05 \mathrm{~kg} / \mathrm{m}^{3}\end{array}$ & $\begin{array}{c}1.00 \% \\
17.4 \mathrm{~kg} / \mathrm{m}^{3}\end{array}$ & $0 / 4 \mathrm{~mm}$ & $2 / 5 \mathrm{~mm}$ & $\begin{array}{l}\text { Aluminous } \\
\text { cement }\end{array}$ & $\begin{array}{c}\text { Ceramic } \\
\text { powder }\end{array}$ & Water & Plasticizer \\
\hline $\mathrm{A}_{100}$ & $\mathrm{~B}_{100}$ & $\mathrm{C}_{100}$ & 880 & 220 & 900 & 0 & 224 & 22.75 \\
\hline $\mathrm{A}_{95}$ & $\mathrm{~B}_{95}$ & $\mathrm{C}_{95}$ & 880 & 220 & 855 & 45 & 224 & 22.75 \\
\hline $\mathrm{A}_{90}$ & $\mathrm{~B}_{90}$ & $\mathrm{C}_{90}$ & 880 & 220 & 810 & 90 & 224 & 22.75 \\
\hline $\mathrm{A}_{85}$ & $\mathrm{~B}_{85}$ & $\mathrm{C}_{85}$ & 880 & 220 & 765 & 135 & 224 & 22.75 \\
\hline $\mathrm{A}_{80}$ & $\mathrm{~B}_{80}$ & $\mathrm{C}_{80}$ & 880 & 220 & 720 & 180 & 224 & 22.75 \\
\hline $\mathrm{A}_{75}$ & $\mathrm{~B}_{75}$ & $\mathrm{C}_{75}$ & 880 & 220 & 675 & 225 & 224 & 22.75 \\
\hline
\end{tabular}

TABLE 2. Composition of the used mixtures.

etc. $\mathrm{Fe}_{2} \mathrm{O}_{3}$ limits the usability of all materials for an application in a high temperature environment; a recommendation from available literature coincides to limit the maximum amount on $4 \%$ of weight [24]. The utilization of waste material, which additionally had been exposed to a temperature loading process - during brick manufacturing, made the added value. The ceramic powder seems to be an alternative for metakaolin or microsilica for the refractory composite production.

Mixing procedure. The mixing procedure took place in a horizontal laboratory mixing machine; the first phase consisted of the homogenization of aggregates and fine components. $50 \%$ of water and $50 \%$ of carbon fibres were added in the second phase. The rest of water with the plasticizer was added in the third phase. The process of mixing ends after 2 minutes, when the remaining part of fibres and their homogenization took place. The mixing process is similar to an ultra-high performance concrete production described for example in [25].

\section{EXPERIMENTAL ANALYSIS}

The influence of elevated temperatures on a refractory cement composite was investigated by an exposure to two different temperature levels $\left(600^{\circ} \mathrm{C}\right.$ and $\left.1000^{\circ} \mathrm{C}\right)$ for 240 minutes in an electric furnace. The samples were 28 days old. The temperature in the furnace rose up by $10^{\circ} \mathrm{C} / \mathrm{min}$. Reference samples were dried at $105^{\circ} \mathrm{C}$ for 72 hours. A measuring of basic and advanced mechanical properties and their decrease describes the effect of the elevated temperatures $\left(600{ }^{\circ} \mathrm{C}\right.$ and $1000^{\circ} \mathrm{C}$ ). The experimental analysis (bulk density, dynamic modulus of elasticity, flexural strength, compressive strength and fracture energy) was performed after the temperature loading process. In total, nine specimens were produced from each mixture (three specimens were reference, three were exposed to $600{ }^{\circ} \mathrm{C}$ and three were exposed to $1000^{\circ} \mathrm{C}$ ).

Dynamic modulus of elasticity. The evaluation of the non-destructive measurement of dynamic modulus of elasticity took place according to

$$
E_{\mathrm{cu}}=\varrho v_{\mathrm{L}}^{2} \frac{1}{k^{2}} \cdot 10^{-6},
$$

where $E_{\mathrm{cu}}$ is the dynamic modulus of elasticity [MPa], $\varrho$ is the bulk density of measured material $\left[\mathrm{kg} / \mathrm{m}^{3}\right]$, $v_{\mathrm{L}}$ is the pulse velocity of ultrasonic waves $[\mathrm{m} / \mathrm{s}], k$ is the characteristics of the environment [-], [27].

A Proceq Punditlab + testing device has been used to determine the ultrasound speed $v_{\mathrm{L}}$. The pulse transducer $(54 \mathrm{kHz})$ and the receiver were positioned on the opposite sides of the prismatic specimen to require only the one-dimension adjustment. For the performed test arrangement, $k=1$ was used. This non-destructive method finds its application in describing the effect of the influence of high temperature [26] or other non-force loads on mechanical properties of building materials.

Compressive and flexural strength. The mechanical properties of a common cement composite are tested according to Czech standards; for the purpose of this experimental program, the compressive strength $\left(f_{\mathrm{c}}\right)$ and the flexural strength $\left(f_{\mathrm{t}}\right)$ of refractory cement composite were tested in an accordance with CSN EN 196-1 28. Three-point bending test with the clear span of supports $100 \mathrm{~mm}$ was performed by universal loading machine MTS100. The test was controlled by the increase of the deformation $(0.02 \mathrm{~mm} / \mathrm{s})$. The flexural strength was calculated, based on the theory of plasticity with the help of the maximum reached force. The compressive strength was investigated on two fragments left after the bending test. The area of the cross section $\left(40 \times 40 \mathrm{~mm}^{2}\right)$ was demarcated 


\begin{tabular}{lcccccccc}
\hline Mixture & \multicolumn{2}{c}{$105^{\circ} \mathrm{C}$} & & \multicolumn{2}{c}{$600^{\circ} \mathrm{C}$} & & \multicolumn{2}{c}{$1000^{\circ} \mathrm{C}$} \\
\cline { 2 - 3 } & {$\left[\mathrm{kg} / \mathrm{m}^{3}\right]$} & {$[\%]$} & & {$\left[\mathrm{kg} / \mathrm{m}^{3}\right]$} & {$[\%]$} & & {$\left[\mathrm{kg} / \mathrm{m}^{3}\right]$} & {$[\%]$} \\
\hline $\mathrm{A}_{100}$ & 2290 & 100 & & 2175 & 95.0 & & 2070 & 90.4 \\
$\mathrm{~A}_{95}$ & 2270 & 100 & & 2160 & 95.2 & & 2030 & 89.4 \\
$\mathrm{~A}_{90}$ & 2250 & 100 & & 2110 & 93.8 & & 2040 & 90.7 \\
$\mathrm{~A}_{85}$ & 2250 & 100 & & 2090 & 92.9 & & 2040 & 90.7 \\
$\mathrm{~A}_{80}$ & 2220 & 100 & & 2085 & 93.9 & & 2030 & 91.4 \\
$\mathrm{~A}_{75}$ & 2195 & 100 & & 2035 & 92.7 & & 1980 & 90.2 \\
\hline $\mathrm{B}_{100}$ & 2250 & 100 & & 2125 & 94.4 & & 2080 & 92.4 \\
$\mathrm{~B}_{95}$ & 2240 & 100 & & 2110 & 94.2 & & 2075 & 92.6 \\
$\mathrm{~B}_{90}$ & 2220 & 100 & & 2120 & 95.5 & & 2070 & 93.2 \\
$\mathrm{~B}_{85}$ & 2200 & 100 & & 2185 & 99.3 & & 2070 & 94.1 \\
$\mathrm{~B}_{80}$ & 2210 & 100 & & 2100 & 95.0 & & 2070 & 93.7 \\
$\mathrm{~B}_{75}$ & 2210 & 100 & & 2090 & 94.6 & & 2060 & 93.2 \\
\hline $\mathrm{C}_{100}$ & 2205 & 100 & & 2120 & 96.1 & & 2070 & 93.9 \\
$\mathrm{C}_{95}$ & 2165 & 100 & & 2110 & 97.5 & & 2065 & 95.4 \\
$\mathrm{C}_{90}$ & 2160 & 100 & & 2105 & 97.5 & & 2060 & 95.4 \\
$\mathrm{C}_{85}$ & 2150 & 100 & & 2110 & 98.1 & & 2050 & 95.3 \\
$\mathrm{C}_{80}$ & 2140 & 100 & & 2100 & 98.1 & & 2050 & 95.8 \\
$\mathrm{C}_{75}$ & 2130 & 100 & & 2095 & 98.4 & & 2040 & 95.8 \\
\hline
\end{tabular}

TABLE 3. Values of bulk density $\varrho$ (before and after exposure to elevated temperatures).

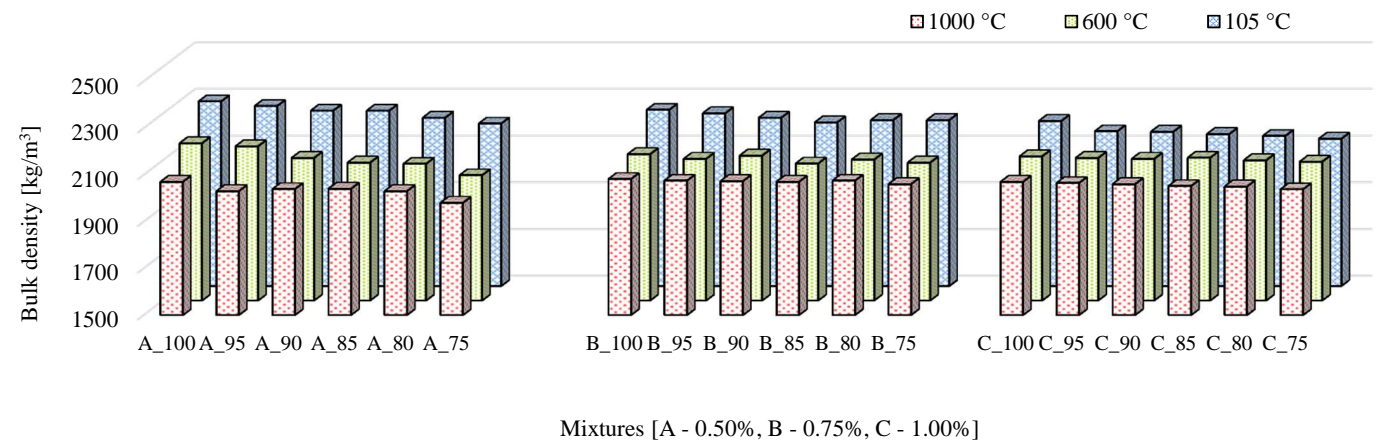

Figure 2. Evaluation of bulk density.

by a loading-device, which was put into the loading machine EU40. This test was also controlled by the increase of the deformation $(0.02 \mathrm{~mm} / \mathrm{s})$.

Fracture energy. Cement composite, as a quasifragile material, shows the fracture process zone behind an existing notch or crack front. Due to the micro-cracking, the softening of the material took place. The experiment was arranged without a notch to monitor the entire destruction of the specimen, which was exposed to the elevated temperatures, because the crack initiation starts on the surface, which is the most exposed area of the specimen. The selected approach allows a better comparison of the influence of fibres. For the evaluation of fracture energy, we can successfully use a bending test, where the load-deflection dependence is recorded. Based on the recommendation of RILEM [29], fracture energy was calculated according as

$$
G_{\mathrm{f}}=\frac{1}{A} \int_{\delta_{0}}^{\delta_{\max }} F(\delta) \mathrm{d} \delta,
$$

where $G_{\mathrm{f}}$ is the fracture energy $\left[\mathrm{J} / \mathrm{m}^{2}\right], A$ is the section area $\left[\mathrm{m}^{2}\right], F$ is the force $[\mathrm{N}], \delta$ is the deflection $[\mathrm{m}]$, $F(\delta)$ is the load-deflection from bending test.

A load-deflection diagram has been derived based on the data record from MTS 100 loading device.

Due to the bending test arrangement without notch, the fracture energy was calculated from the area under the load-deflection diagram before the peak load.

\section{Results AND Discussion}

It is necessary to mention that the temperature loading started at the age of 28 days. All specimens had been stored in a $90 \%$ humidity environment with a temperature of $22^{\circ} \mathrm{C}$. All samples were dried at $105^{\circ} \mathrm{C}$ for 72 hours to evaporate free water from the inner structure. The drying process took place due to the technical limit of the used electric furnace. The drying process was a preventive step to limit the explosive spalling due to evacuation of steam and consequent risks of furnace damages. The first group of three 


\begin{tabular}{|c|c|c|c|c|c|c|}
\hline \multirow[t]{2}{*}{ Mixture } & \multicolumn{2}{|c|}{$105^{\circ} \mathrm{C}$} & \multicolumn{2}{|c|}{$600^{\circ} \mathrm{C}$} & \multicolumn{2}{|c|}{$1000^{\circ} \mathrm{C}$} \\
\hline & $f_{\mathrm{c}}$ & $f_{\mathrm{t}}$ & $f_{\mathrm{c}}$ & $f_{\mathrm{t}}$ & $f_{\mathrm{c}}$ & $f_{\mathrm{t}}$ \\
\hline $\mathrm{A}_{100}$ & 69.5 & 8.2 & 36.1 & 2.7 & 24.6 & 1.9 \\
\hline $\mathrm{A}_{95}$ & 70.9 & 10.2 & 35.3 & 2.9 & 21.5 & 1.8 \\
\hline $\mathrm{A}_{90}$ & 72.8 & 10.6 & 37.6 & 3.7 & 21.5 & 2.1 \\
\hline $\mathrm{A}_{85}$ & 67.6 & 10.1 & 33.0 & 3.8 & 25.6 & 3.1 \\
\hline $\mathrm{A}_{80}$ & 59.5 & 9.7 & 31.6 & 3.2 & 22.8 & 2.5 \\
\hline $\mathrm{A}_{75}$ & 56.7 & 8.4 & 33.0 & 2.6 & 24.6 & 2.5 \\
\hline $\mathrm{B}_{100}$ & 86.2 & 9.7 & 53.4 & 3.5 & 30.3 & 1.8 \\
\hline $\mathrm{B}_{95}$ & 91.1 & 10.4 & 55.3 & 4.3 & 32.0 & 2.2 \\
\hline $\mathrm{B}_{90}$ & 97.2 & 10.8 & 53.9 & 3.9 & 35.3 & 2.9 \\
\hline $\mathrm{B}_{85}$ & 83.1 & 10.6 & 47.7 & 4.1 & 35.1 & 2.3 \\
\hline $\mathrm{B}_{80}$ & 85.1 & 10.5 & 45.4 & 3.2 & 31.2 & 2.7 \\
\hline $\mathrm{B}_{75}$ & 72.7 & 10.3 & 43.9 & 3.1 & 30.7 & 2.8 \\
\hline $\mathrm{C}_{100}$ & 73.6 & 9.4 & 40.0 & 3.8 & 27.5 & 3.2 \\
\hline $\mathrm{C}_{95}$ & 88.6 & 10.1 & 42.5 & 4.0 & 31.9 & 3.0 \\
\hline $\mathrm{C}_{90}$ & 95.3 & 10.3 & 39.4 & 3.8 & 28.1 & 3.0 \\
\hline $\mathrm{C}_{85}$ & 81.9 & 10.6 & 38.7 & 3.9 & 24.2 & 3.2 \\
\hline $\mathrm{C}_{80}$ & 70.8 & 10.4 & 35.9 & 3.9 & 30.1 & 2.8 \\
\hline $\mathrm{C}_{75}$ & 60.5 & 9.2 & 37.6 & 3.8 & 24.7 & 2.6 \\
\hline
\end{tabular}

TABLE 4. Values of compressive strength $f_{\mathrm{c}}$ and flexural strength $f_{\mathrm{t}}[\mathrm{MPa}]$.

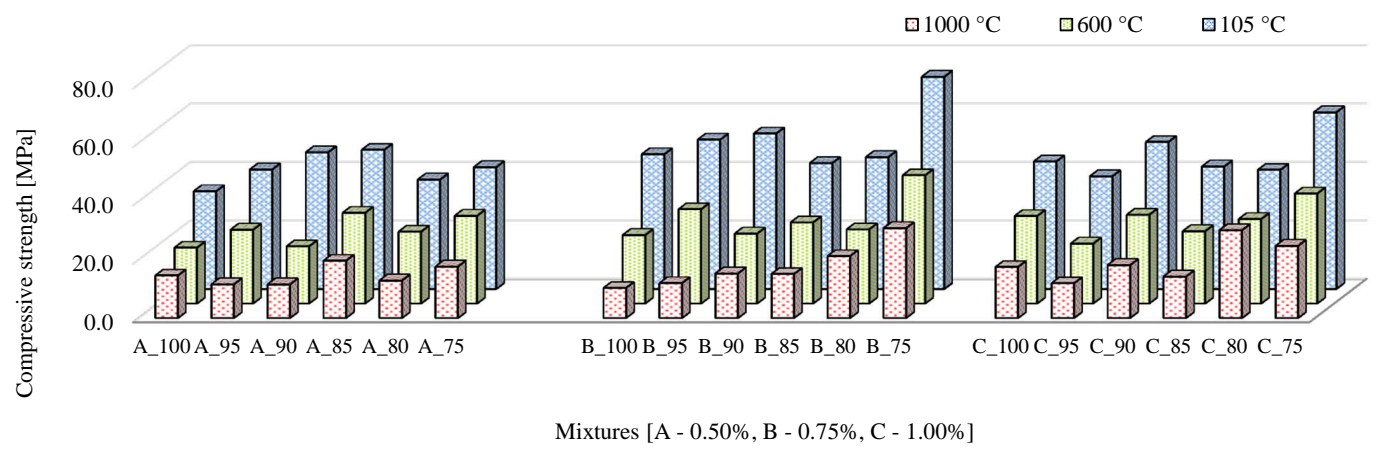

FiguRE 3. Evaluation of compressive strength.

specimens was a reference, the second group was exposed to $600{ }^{\circ} \mathrm{C}$ for three hours and the last group was exposed to $1000{ }^{\circ} \mathrm{C}$ for three hours. At first, the measurement of weigh and dynamic modulus of elasticity took place, then, the destructive testing was carried out.

\subsection{BUlK DENSITY}

Table 4 summarizes the calculated values of the bulk density. The weight was measured after the thermal loading (at approximately $60^{\circ} \mathrm{C}$ ), while the dimensions were measured at laboratory conditions before the thermal loading. Two technological parameters reduce the values of the bulk density - increasing the amount of fibres and increasing the amount of ceramic fibres. An approximate $3 \%$ decrease of bulk density is caused by the dosage of $25 \%$ of ceramic powder (for the reference specimens without a temperature load). A dosage of $1.00 \%$ of carbon fibres reduces the bulk density by $3.5 \%$, in comparison with $0.50 \%$ of fibres. The highest decrease of the bulk density is caused by the action of the temperature load on $1000^{\circ} \mathrm{C}$ level, where the decrease slows with an increasing amount of fibres (from $9.7 \%$ to $5.2 \%$ ). Figure 2 describes the dependence of the bulk density on the temperature loading and also on technological parameters.

\subsection{MeChanicAl AND FRACTURE PARAMETERS}

\subsubsection{Compressive strength}

From the point of view of compressive strength, the fibres dosage of $0.50 \%$ is not sufficient. This is mostly caused by the technological aspects - the amount of $0.5 \%$ caused a bleeding of technological water. Reasonable values are achieved on specimens with $0.75 \%$ and $1.00 \%$ dosage. The decrease of compressive strength due to the action of the elevated temperature is not so rapid like in the case of flexural strength. Action of $600^{\circ} \mathrm{C}$ causes an average decrease of the compressive strength to $55 \%$ of original level, while 


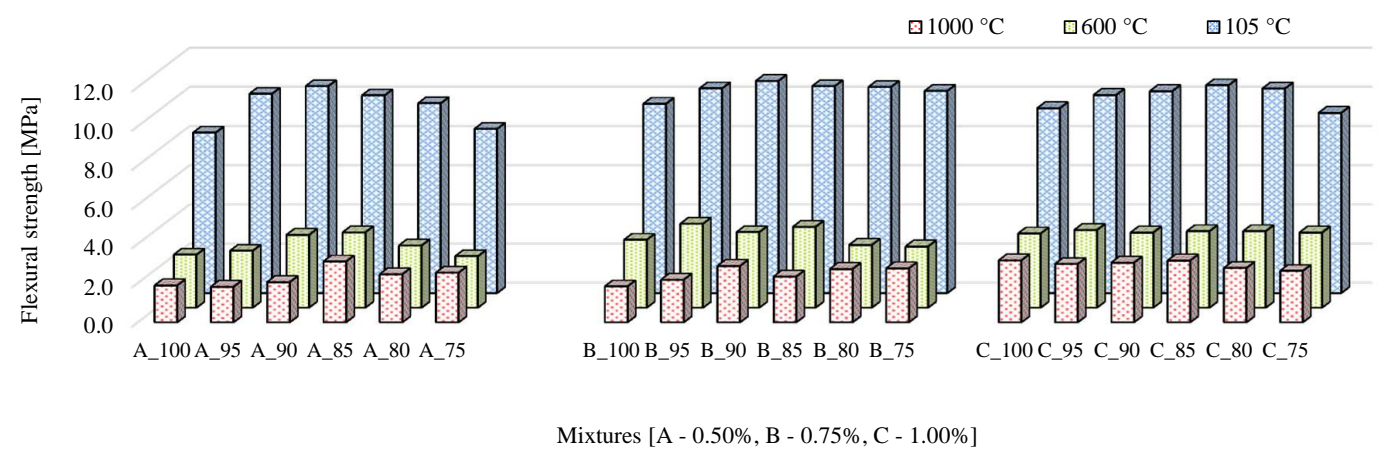

Figure 4. Evaluation of flexural strength.

\begin{tabular}{|c|c|c|c|c|c|c|}
\hline \multirow[t]{2}{*}{ Mixture } & \multicolumn{2}{|c|}{$105^{\circ} \mathrm{C}$} & \multicolumn{2}{|c|}{$600^{\circ} \mathrm{C}$} & \multicolumn{2}{|c|}{$1000^{\circ} \mathrm{C}$} \\
\hline & $E_{\mathrm{cu}}$ & $G_{\mathrm{f}}$ & $E_{\mathrm{cu}}$ & $G_{\mathrm{f}}$ & $E_{\mathrm{cu}}$ & $G_{\mathrm{f}}$ \\
\hline $\mathrm{A}_{100}$ & 29.1 & 260.4 & 7.4 & 81.6 & 5.5 & 47.8 \\
\hline $\mathrm{A}_{95}$ & 27.5 & 280.5 & 7.4 & 92.0 & 5.7 & 50.2 \\
\hline $\mathrm{A}_{90}$ & 30.1 & 280.2 & 7.3 & 106.6 & 6.2 & 49.0 \\
\hline $\mathrm{A}_{85}$ & 34.1 & 278.3 & 9.3 & 125.9 & 8.4 & 69.3 \\
\hline $\mathrm{A}_{80}$ & 30.0 & 380.1 & 9.2 & 137.9 & 7.7 & 74.0 \\
\hline $\mathrm{A}_{75}$ & 29.9 & 273.1 & 10.1 & 129.9 & 10.1 & 52.3 \\
\hline $\mathrm{B}_{100}$ & 36.6 & 277.9 & 7.2 & 83.4 & 6.5 & 50.5 \\
\hline $\mathrm{B}_{95}$ & 38.0 & 291.6 & 7.8 & 89.2 & 6.4 & 58.9 \\
\hline $\mathrm{B}_{90}$ & 34.1 & 315.0 & 8.4 & 87.3 & 6.1 & 76.6 \\
\hline $\mathrm{B}_{85}$ & 34.2 & 296.3 & 8.7 & 90.0 & 6.7 & 54.1 \\
\hline $\mathrm{B}_{80}$ & 36.3 & 305.0 & 8.6 & 127.7 & 6.7 & 72.3 \\
\hline $\mathrm{B}_{75}$ & 37.2 & 297.5 & 8.9 & 135.6 & 7.0 & 80.9 \\
\hline $\mathrm{C}_{100}$ & 30.8 & 338.2 & 8.4 & 108.1 & 7.9 & 54.5 \\
\hline $\mathrm{C}_{95}$ & 28.5 & 348.4 & 8.7 & 120.8 & 7.2 & 68.3 \\
\hline $\mathrm{C}_{90}$ & 34.1 & 340.0 & 8.4 & 115.3 & 6.6 & 63.9 \\
\hline $\mathrm{C}_{85}$ & 31.6 & 361.0 & 8.6 & 124.6 & 6.6 & 65.3 \\
\hline $\mathrm{C}_{80}$ & 31.2 & 359.6 & 8.2 & 115.3 & 7.0 & 65.6 \\
\hline $\mathrm{C}_{75}$ & 31.4 & 311.3 & 8.1 & 101.6 & 6.9 & 54.9 \\
\hline
\end{tabular}

TABLE 5. Summary of dynamic modulus $E_{\mathrm{cu}}[\mathrm{GPa}]$ of elasticity and fracture energy $G_{\mathrm{f}}\left[\mathrm{J} / \mathrm{m}^{2}\right]$.

after an exposure to $1000^{\circ} \mathrm{C}$, the residual compressive strength achieved approx. $40 \%$ of its original values.

\subsubsection{FleXural STREnGth}

Fibres dosage does not influence the flexural strength of reference specimens dried at $105^{\circ} \mathrm{C}$, while the fibres affect the flexural strength especially after the action of $1000^{\circ} \mathrm{C}$. The residual flexural strength after the action of $1000{ }^{\circ} \mathrm{C}$ corresponds to approximately $30 \%$ of the original strength. Figure 4 evaluates the dependence of flexural strength on the type of the temperature load.

\subsubsection{Fracture ENERGy}

The fracture characteristics are not ordinarily mentioned in a common experimental investigation of cement composites, including refractories. Increasing the amount of fibres positively affects fracture energy; in average, up $15 \%$ in reference specimens without the temperature load (difference between $0.50 \%$ and $1.00 \%$ of carbon fibres). The Fracture energy of spec- imens exposed to the elevated temperature is approximately on the same level (see Figure 5). The difference of fibre dosage in the case of reference specimens can be quantified as approx. $20 \%$ (the increase of fracture energy between $0.5 \%$ and $1.0 \%$ ). We can conclude that from the point of view of fracture energy, $20 \%$ of ceramic powder is the most suitable option.

\subsubsection{Dynamic modulus of Elasticity}

The dynamic modulus of elasticity is rapidly influenced by the action of temperature (see Figure 6), due to the interconnection with the decrease of bulk density. The average reference dynamic modulus of elasticity of mixture with $0.75 \%$ of fibres corresponds to $120 \%$ of specimens with $0.5 \%$. The dynamic modulus of elasticity after the action of $600{ }^{\circ} \mathrm{C}$ and $1000{ }^{\circ} \mathrm{C}$ achieves similar average values, however there can be minor differences observed between the studied mixtures. As mentioned above, this method is suitable for the description of gradual changes, e.g., as an effect of the elevated temperatures. 


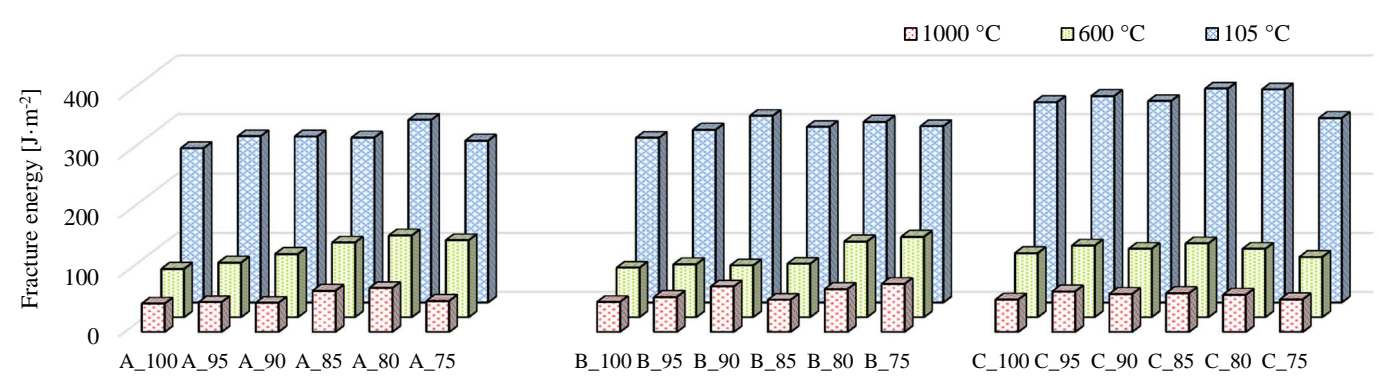

Mixtures [A - $0.50 \%, \mathrm{~B}-0.75 \%, \mathrm{C}-1.00 \%$ ]

FiguRE 5. Evaluation of fracture energy.

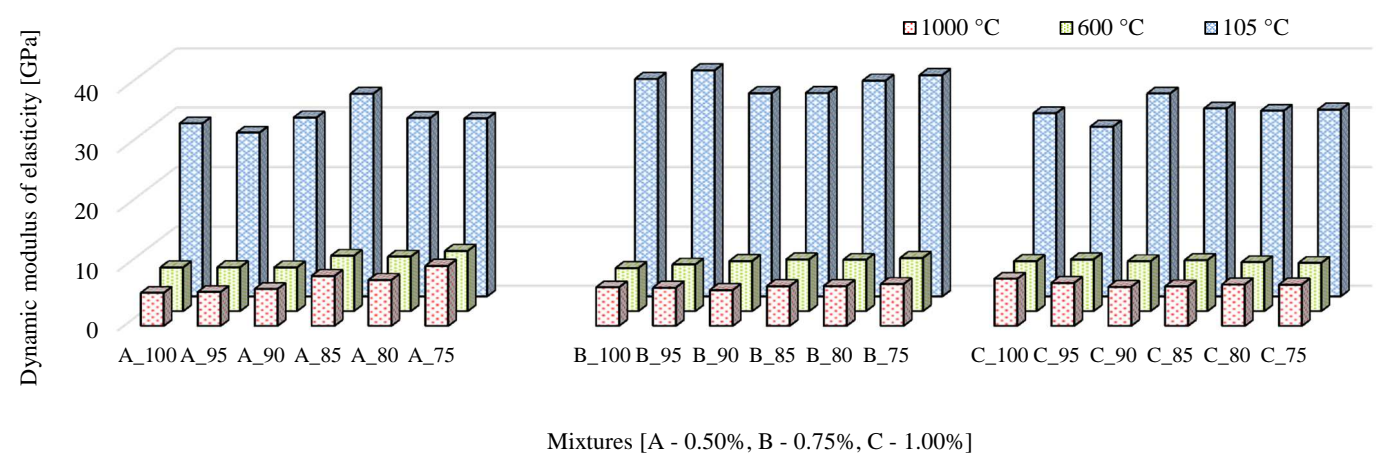

FIGURE 6. Evaluation of dynamic modulus of elasticity.

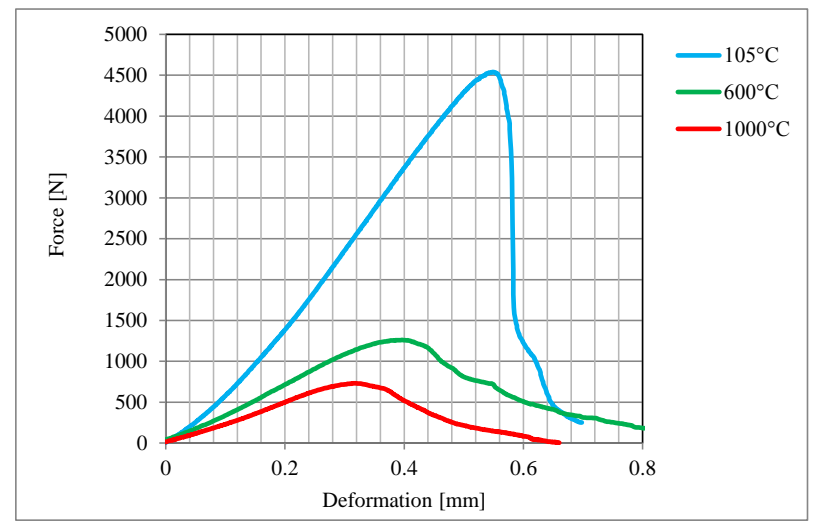

Figure 7. Load-deflection diagram of $\mathrm{A}_{80}$.

\subsection{Ductile Behaviour}

The failure modes of specimens made from mixtures with $80 \%$ of aluminous cement and $20 \%$ of ceramic powder are described on Figure 7 ( $0.50 \%$ of fibres) on Figure 8 (0.75\% of fibres) and on Figure 9 (1.00\% of fibres). The effect of $600{ }^{\circ} \mathrm{C}$ and $1000^{\circ} \mathrm{C}$ on the failure mode of $600{ }^{\circ} \mathrm{C}$ and $1000^{\circ} \mathrm{C}$ was investigated in comparison with $105^{\circ} \mathrm{C}$ (reference). The maximal deformation of reference's specimen decreases with the increasing amount of carbon fibres - especially the difference between $0.75 \%$ and $1.00 \%$ is perceptible. Also the deformation corresponding to the maximum achieved force during the bending test of specimens exposed to $1000{ }^{\circ} \mathrm{C}$ follow the trend described above (decreasing deformation with increasing amount of fibres). The fragile failure of reference specimens

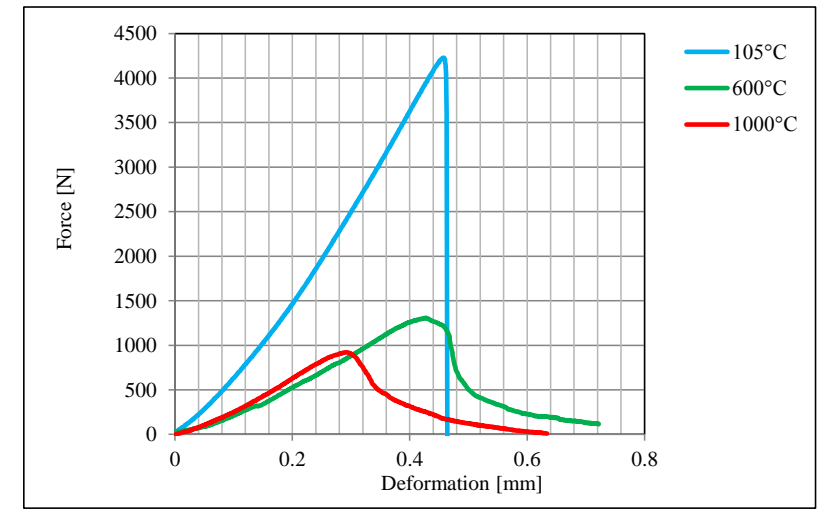

FiguRE 8. Load-deflection diagram of $\mathrm{B}_{80}$.

$\left(105^{\circ} \mathrm{C}\right)$ occurs independently of the fibre amount, while specimens after the thermal loading $\left(600{ }^{\circ} \mathrm{C}\right.$ and especially $1000^{\circ} \mathrm{C}$ ) show a ductile behaviour.

\section{Conclusions}

Based on the performed experimental program and evaluation of the results, we can draw several conclusions. All basic and mechanical properties were measured on 162 prismatic specimens in total, which were tested after being exposed to elevated temperatures (reference at $105^{\circ} \mathrm{C}, 600^{\circ} \mathrm{C}$ and $1000^{\circ} \mathrm{C}$ ). According to the results of the destructive testing, following conclusions can be drawn:

(1.) The total amount of the fibre dosage influences the workability of the fresh mixture, where the maximum amount of $1.0 \%$ of volume means the 


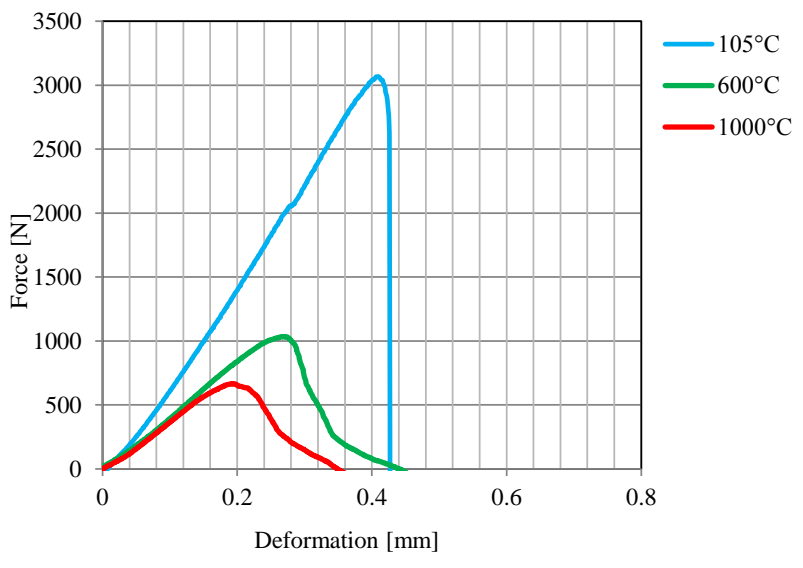

FiguRE 9. Load-deflection diagram of $\mathrm{C}_{80}$.

limit for a sufficient workability. A higher amount than $1.0 \%$ of fibres is not possible to homogenize in the mixture, which causes clusters of fibres. The mixture with a dosage of $0.5 \%$ of volume achieves self-flow characteristics of fresh mixture. Dosage of $25 \%$ of ceramic powder leads to an average $3.2 \%$ decrease of bulk density (in comparison with $100 \%$ of aluminous cement).

(2.) Increasing the amount of carbon fibres positively influences tensile characteristics (flexural strength fcm), especially after the exposure to high temperature, mainly $1000^{\circ} \mathrm{C}$. This phenomenon confirms the premise of maintaining a mutual cohesion between the surface of fibres and hydration products after the temperature loading. Regardless of the amount of fibres, the tensile characteristics of the composite without the temperature loading are approximately on the same level. The values of the fracture energy are influenced by carbon fibres in a similar way as the flexural strength is. The ceramic powder positively effects fracture energy, especially after an exposure to a temperature load.

The compressive strength does not decrease so rapidly as the other mechanical properties. The most suitable amount of carbon fibres is $0.75 \%$ of the total volume. A dosage of $1.00 \%$ of carbon fibres is the limit for achieving a satisfactory workability of the fresh mixture.

(3.) The action of elevated temperatures changes the failure mode of specimens during the bending test. Originally brittle failure mode of reference specimens changes to a mode with a softening part of the load-deflection diagram, because of the activation of carbon fibres. The deflection at maximum force is lower in the case of specimens exposed to the elevated temperature.

The results of the performed experimental program clearly showed a successful application of carbon fibres and fine ceramic powder for a refractory cement composite production. Based on the evaluation of the mechanical parameters, the most suitable solution is the combination of $720 \mathrm{~kg} / \mathrm{m}^{3}$ of aluminous cement Secar®71 and $180 \mathrm{~kg} / \mathrm{m}^{3}$ of a fine ground ceramic powder. The optimal dosage of carbon fibres, based on the workability of the fresh mixture and mechanical properties, is $0.75 \%$ of the total volume. The application of fine ground ceramic powder suitably complements the granularity (grain size between aluminous cement and basalt aggregate) and reduces the environmental impact and $\mathrm{CO}_{2}$ production (reduction of aluminous cement consumption, which is highly energy-intensive).

\section{ACKNOWLEDGEMENTS}

This research work was supported by the Czech Science Foundations under project No.: P105/12/G059 "Cumulative time dependent processes in building materials and structures".

\section{REFERENCES}

[1] High Aluminia Cements \& Chemical Binders, Institute of Refractories Engineering, IRE, South Africa, (1996), pp. 1-15.

[2] Hipedinger, N., Scian, A., Aglietti, E.: Refractory concrete of chemical bond with diverse aggregate, Procedia Materials Science 1, (2012), pp. 425-431. DOI:10.1016/j.mspro.2012.06.057

[3] Studart A.R., Pandolfelli, V.C., Tervoort, E., Gauckler, L.J.: Selection of dispersants for high-alumina zero-cement refractory castables, Journal of the European Ceramic Society 23, (2003), pp. 997-1004. DOI:10.1016/S0955-2219(02)00275-3

[4] Harmuth, H., Rieder, K., Krobath. M., Tschegg, E.: Investigation of the nonlinear fracture behaviour of ordinary ceramic refractory materials, Materials Science and Engineering (1996), pp. 53-62,

[5] Lam, S.S., Bu, B., Liu, Q., Ivy Fung-Yuen Ho: Monotonic and Cyclic Behavior of High-Strength Concrete with Polypropylene Fibers at High Temperature, ACI Materials Journal 109 (2012), pp. 323-330.

[6] Kalifa, P., Chéné, G., Gallé, C.: High-Temperature Behaviour of HPC with Polypropylene Fibres from Spalling to Microstructure, Cement and Concrete Research 31, (2001), pp. 1487-1499. DOI:10.1016/S0008-8846(01)00596-8

[7] Holčapek, O.: Resistance of Refractory Cement Composite to Cyclic Temperature Loading, Key Engineering Materials 677, (2015), pp. 23-28. DOI:10.4028/www.scientific.net/KEM.677.23

[8] Montgomery, R.: Heat-resisting and refractory concretes, Advanced concrete technology, Oxford (2003).

[9] Ali, F., O'Connor, D.: Structural performance of rotationally restrained steel columns in fire, Fire Safety Journal 36, (2001), pp. 679-691. DOI:10.1016/S0379-7112(01)00017-0

[10] Burton, K.J., Brownlee, N.A., Mahar, A., et. al. Diffuse malignant mesothelioma and synchronous lung cancer: A clinicopathological study of 18 cases. Lung Cancer 95, (2016), pp. 1-7. DOI:10.1016/j.lungcan.2016.02.007 
[11] Kashcheev, I.D., Zemlyanoi, K.G., Podkopaev, S.A., et. al.: Use of Carbon Fibers in Refractory Materials, Refractories and Industrial Ceramics 50, (2009), pp. $15-19$.

[12] Kahanji, Ch., Ali, F., Nadjai, A., Alarm, N..: Effect of curing temperature on the behaviour of UHPFRC at elevated temperatures, Construction and Building Materials 182, (2018), pp. 670-681. DOI:10.1016/j.conbuildmat.2018.06.163

[13] Yu, R., Song, Q., Wang, X., Zhang, Z., Shui, Z., Brouwers, H.: Sustainable Development of Ultra-High Performance Fibre Reinforced Concrete (UHPFRC): Towards to an optimized concrete matrix and efficient fibre application, Journal of Cleaner Production, Vol. 162, (2017), pp. 220-233. DOI:10.1016/j.jclepro.2017.06.017

[14] Reiterman, P., Holčapek O., Jogl. M., Konvalinka, P.: Physical and Mechanical Properties of Composites Made with Aluminous Cement and Basalt Fibers Developed for High Temperature Application, Advances in Materials Science and Engineering, Vol. 2015, (2015), pp. 1-11, DOI:10.1155/2015/703029

[15] Holčapek, O., Reiterman, P., Konvalinka, P.: Fracture characteristics of refractory composites containing metakaolin and ceramic fibers, Advances in Mechanical Engineering, (2015), pp. 1-13, DOI:10.1177/1687814015573619

[16] Jogl, M., Reiterman, P., Holčapek, O., Kotátková J., Influence of high-temperature on polycarboxyte superplasticizer in aluminous cement based fibre composites, Advanced Materials Research 982, (2014), pp. 125-129. DOI:10.4028/www.scientific.net/AMR.982.125

[17] Nilforoushan, M., R., et al.: Correlations of Unhydrous Phases Present in Calcium Aluminate Cement with its Workability, Refractories Application and News 11/1 (2006) pp. 17.

[18] Nilforoushan, M. R., Talebian, N.: The Hydration Products of a refractory Calcium Aluminate Cement at Low Temperatures, Iranian Journal Chemistry Chemical Engineering 26/2, (2007).
[19] Rambo, D.A.S., Silva, F.A., Filho, R.D.T., Gomes, O.F.M.: Effect of elevated temperatures on the mechanical behaviour of basalt textile reinforced refractory concrete, Materials and Design 65 (2015), pp. 24-33. DOI:10.1016/j.matdes.2014.08.060

[20] Kashcheev, I. D.: Oxide-Carbon Refractories, Intermet Inzhinirig, Moscow (2000).

[21] Pavlů, T., Boehme, L., Hájek, P.: Influence of recycled aggregate quality on the mechanical properties of concrete, Komunikacie 16 (4), (2014), pp. 35-40.

[22] Subasi, S., Ozturk, H., Emiroglu, M.: Utilizing of waste ceramic powders as filler material in self-consolidating concrete, Construction and Building Materials 149, (2017), pp. 567-574. DOI:10.1016/j.conbuildmat.2017.05.180

[23] Čáchová, M., Vejmelková, E., Polozhiy, K., Černý, R.: Pore system and hydric properties of two different lime plasters with finely crushed brick, Key Engineering Materials 675, (2016), pp. 597-600. DOI:10.4028/www.scientific.net/KEM.675-676.597

[24] Eze, E.O., Onabanjo, S.A.: Heating effects on physical and strength characteristics of fireclay from the Nigerian Coal Measures Formation, Applied Clay Science 9/5 (1995), pp. 397-406. DOI:10.1016/0169-1317(94)00024-K

[25] Sovják, R., Vavřiník, T., Zatloukal, J., Máca, P., Mičunek, T., Frydrýn, M.: Resistance of slim UHPFRC targets to projectile impact using in-service bullets, International Journal of Impact Engineering Vol. 76, (2015), pp. 166-177. DOI:10.1016/j.ijimpeng.2014.10.002

[26] Holčapek, O., Reiterman, P., Jogl, L., Konvalinka, P.: Destructive and non-destructive testing of high temperature influence on refractory fiber composite, Advanced Materials Research 982, (2014), pp. 145-148. DOI:10.4028/www.scientific.net/AMR.982.145

[27] CSN EN 12 504-4: Testing of concrete - Part 4: Determination of ultrasonic pulse velocity (2005).

[28] Czech Standard CSN EN 196-1: Methods of testing cement - Part 1: Determination of strength (2005).

[29] RILEM, Materials and Structures 18, 106, (1985), pp. 285-290. 